\title{
Evaluating the Performance of Inflation Targeting
}

\author{
Jenq Fei Chu ${ }^{1} \&$ Siok Kun Sek ${ }^{1}$ \\ ${ }^{1}$ School of Mathematical Sciences, Universiti Sains Malaysia, Malaysia \\ Correspondence: Siok Kun Sek, School of Mathematical Sciences, Universiti Sains Malaysia, 11800 USM \\ Penang, Malaysia. Tel: 60-4-653-5285. E-mail: sksek@usm.my
}

Received: June 11, 2012

doi:10.5539/ijef.v4n9p69
Accepted: July 11, $2012 \quad$ Online Published: July 30, 2012

URL: http://dx.doi.org/10.5539/ijef.v4n9p69

\begin{abstract}
Applying the Ordinary Least Squares method (OLS) and panel data analysis, the performance of Inflation Targeting (IT) regime is analyzed in 11 developed and developing countries. We compare the economic performance (i) between pre-IT and post-IT periods and (ii) between developing economies and developed economies that have implemented IT. The performance of IT is evaluated based on (i) inflation persistency; (ii) output growth; (iii) exchange rate volatility; (iv) deviation of inflation and (v) output gap. Besides, the disinflation cost/trade-off relationship between output gap and deviation in inflation is tested. The implementation of IT has effectively reduced the inflation rate and stimulated high output growth. The reduction of inflation rate is larger in developing economies but the gain in higher growth is larger in developed economies. On the other hand, there is strong evidence that IT has led to higher volatility in exchange rate of developing countries. Furthermore, the deviations of inflation and output gap have increased in the post-IT period in few economies. However, results failed to prove that IT has led to the trade-off relationship between inflation and output gap as the trade-off relationship between inflation and output gap is also detected in the pre-IT period. Overall results provide evidences on better economies condition under IT regime.
\end{abstract}

Keywords: inflation targeting, panel data analysis, output growth, output gap

\section{Introduction}

Inflation targeting (IT) regime has been widely adopted since 1990. Nowadays, IT has emerged as a promising new approach instead of the previous monetary policies. The uniqueness of IT: publicly announcing and pursuing specific targets for the rate of inflation; have attracted the attention of many researchers to evaluate its performance. However, the effectiveness of this policy in reducing the inflation rate, volatility in exchange rate and output gap still remains controversial among researchers and policy makers.

In this study, we conduct empirical analysis to evaluate the performance of IT regime. Different approaches are applied to reveal the effectiveness of IT regime compared to the pre-IT period and relative to the non-IT targeters. In general, there are three objectives in this study. First we seek to compare the persistency in five economic indicators between the pre-IT and post-IT periods. The five indicators are the inflation rate, growth rate, exchange rate, deviation in inflation and output gap in 11 IT countries. Second, we compare the performance of IT between the developed and developing economies. Third, we investigate if IT induces disinflation cost i.e. if there any trade-off relationship between inflation and output gap.

Our main findings show that IT manages to boost the economy by leading a higher growth on output and reduction on inflation and does not led to higher volatility in exchange rate. We also find that six out of eleven countries show declines in their deviations in inflations after the implementation of IT. For output gap variable, we find that the implementation of IT has no significant impact on the output gap in all 11 countries. IT has good performance in both developed and developing countries. We cannot say that IT has led to the trade-off relationship between inflation and output gap as the trade-off relationship between inflation and output gap is also detected in the pre-IT period.

The outline of the paper is organized as follow: Section one is the introduction which explains the concepts and background on the existing works. Section two is about the data and methodology. Section three discusses the results and section four concludes the findings. 


\subsection{Material Studied}

\subsubsection{Concept of IT}

IT is a monetary policy strategy that made the achievement of a designated low rate of inflation (McCallum, 2007). According to Mishkin (2000), Kadiǒglu et al. (2000) and Lin and Ye (2008), IT is a monetary policy strategy which involves five elements, i.e. the announcement of medium-term targets for inflation, commitment to price stability, information inclusive strategy is used for deciding the setup of policy instruments, greater transparency of monetary policy through communication with pubic and markets and higher accountability of central bank. There are many advantages that a country can gain from IT, i.e.IT enables monetary policy to focus on domestic considerations and shocks. Political debates are carried out in order to decide on what a central bank can do in the long-run. Besides, kinds of information are counted before the instruments of monetary policy are made. IT is easily understood by the public and therefore it is highly transparent and will increases the accountability of the central bank.

However, Mishkin (2000) and Tutar (2002) also mentioned about the disadvantages of IT. There are seven major disadvantages of IT policy: IT is too rigid, allows too much discretion, has the potential to increase output instability, induces lower economic growth, lower central bank accountability due to the difficulty in controlling the inflation, long lags from the monetary policy instruments to the inflation outcome, IT cannot prevent fiscal dominance, and that the exchange rate flexibility required by IT might cause financial instability (Mishkin, 2000).

Four disadvantages of IT are listed in the study of Tutar (2002). First, IT failed to guarantee a fully success in economy. Second, the forward-looking nature of an IT requires consideration the potentially long lags between changes in monetary policy and their influences on inflation. In other words, wrong forecast of potential inflation can be made by central bank. Third, the rigid structure of the IT regime may lead to inefficient output stabilization. Fourth, it is difficult to control inflation.

To ensure IT to work effectively, several preconditions have to be fulfilled. As discussed in Kadiǒglu et al. (2000), the prerequisites to adopt inflation targeting include central bank independence, exchange rate flexibility, political commitment, the institutional set-up and economic structure. As developing economies need longer time to achieve maturity in these economic aspects, it is argued that developed countries have better condition to adopt IT than developing countries.

Lin and Ye (2008) have the same opinion with Kadiǒglu et al. (2000) that the performance of a given IT regime can be affected by country characteristics. The characteristics mentioned by Lin and Ye (2008) are the government's fiscal position, central bank's desire to limit the movements of exchange rate, its willingness to meet the preconditions of policy adoption, and the time length since the policy adoption.

In order to minimize inflation deviations from target and output deviations from trend, Gosselin et al. (2007) have suggested following features for the monetary policy framework: a low numerical target, a relatively narrow control range, confidentiality voting records, the use of economic models to guide policy decisions, and independence from the government.

\subsubsection{The Performance of IT Regime - Comparison of IT \& Non-IT Targeters}

Countries that adopt the IT regime are specifically named as targeters or IT adopters. According to Mishkin and Schmidt-Hebbel (2007) and Capistrán and Ramos-Francia (2007), emerging (developing) economies have greater enhancement following the adoption of IT than industrial (developed) countries. Emerging economies confront major reductions in output and inflation volatility after adopting the regime of IT, both because they face smaller supply shocks and because they improve their monetary policy competency.

In contrast to emerging inflation targeters, industrial targeters improve their macroeconomic performance only. This is because they face smaller supply shocks. Their monetary policy efficiency levels are already high before the adoption of IT compared with emerging which countries actually deteriorated somewhat after the adoption of IT (Mishkin and Schmidt-Hebbel, 2007).

As in the studies of Brito and Bystedt (2009), GMM estimation method has been applied. They have examined the macroeconomic outcomes of 46 countries (13 IT targeting and 33 non-IT targeting). The results of the comparison show no significant evidence that support the performance of the IT regime. The adoption of IT does not improve economic performance as measured by the behaviour of inflation rate and output growth in developing country. 
Furthermore, Levin, Natalucci and Piger (2004) have applied univariate autoregressive process on two groups of countries: IT and non-IT. Their results are broadly consistent with the implications of the expectations-augmented Philip curve. IT has played a role in anchoring inflation expectations and in reducing inflation persistence. Pétursson (2004) also showed that IT has managed to bring down inflation in 21 IT countries.

In short, we say that more researchers have found a greater gain of IT countries than non-IT countries. On the other hand, argument on the performance of IT in emerging market relative to developed market is still opening for debate.

\subsubsection{Issues for Emerging Economies}

Many researchers such as Calvo and Mendoza (2000) make conclusion that emerging economies are weak in their institutional environment which is not suitable for their policymakers to have too much discretion. These might lead to poor macroeconomic outcomes.

On the other hand, Mishkin (2004) also shares the same thinking as Calvo and Mendoza (2000) but is more optimistic. In the paper of Mishkin (2004), there are five fundamental institutional differences between emerging countries and developed countries which are weak fiscal institutions, weak financial institutions including government prudential regulation and supervision, low credibility of monetary institutions, currency substitution and liability dollarization and vulnerability to sudden stops (of capital inflows).

On the whole, Mishkin (2004) makes conclusion that IT can be an efficient tool for emerging market countries to manage their monetary policy if and only if the emerging market countries focus additional attention on the five institutional developments. Moreover, international financial institutions are recommended to assist the emerging countries in managing their monetary policy effectively.

The upshot of Fraga et al. (2004) shows that the IT-emerging countries are facing more challenging mission than in developed ones due to the more volatile macroeconomic environment and weaker institutions and credibility. However, they find evidences on better economies condition under IT regime for both advanced and emerging countries.

Besides, there are more passive results shown by Brito and Bystedt (2009) where IT-regime fails in stabilizing inflation and output growth in emerging economies. Yet, Gerlach and Tillmann (2010) claim that the introduction of IT has not led to a large change in inflation due to the attitude of the Asian central bank continue to attach with the exchange rate under the adoption of IT.

As conclusion from studies of Fraga et al. (2004), Mishkin (2004) and Calvo and Mendoza (2000), we find that most of the studies in IT-emerging countries claim that emerging countries face higher difficultly to achieve better macroeconomics outcomes compare with the IT-developed ones. However, once the emerging countries have overcome the issues stated in Mishkin (2004) and Gerlach and Tillmann (2010), then the adoption-IT will lead to faster and better macroeconomics outcomes.

\subsection{Area Descriptions}

In this study, we apply two approaches of analysis i.e. Ordinary Least Square (OLS) and panel data analysis. The selected developed countries include Korea, Spain, United Kingdom, Sweden and Finland. Developing countries include South Africa, Brazil, Colombia, Philippines, Poland and Thailand. The sample periods in this study start from January 1980 to December 2010. The data is divided into pre-IT and post-IT periods depending on the data of the IT implementation. The effectiveness of IT depends on the changes of five variables of macroeconomic performance indicators, which are inflation rate $(\pi)$, exchange rate $(e r)$, output growth $(y)$, deviation of inflation $\left(\pi^{d}\right)$ and output gap (gap). 
Table 1. IT adoption date and monetary policy before IT

\begin{tabular}{|c|c|c|c|}
\hline Group & Country & IT adoption date & Monetary policy before the IT adoption \\
\hline \multirow{11}{*}{ Developed } & Korea & 1998M4 & - Monetary Aggregates (M1-1976, M2-mid 1990 and M2 \& MCT-1997) \\
\hline & Spain & 1995M1 & - Fixed Exchange Rate $\quad(1989)$ \\
\hline & & & - Gold Standard (1816) \\
\hline & UK & 1992M10 & - Monetary Aggregates(M3 - late 1970s and early 1980s) \\
\hline & & & - Fixed Exchange Rate(1987-1988) \\
\hline & & & - Gold Standard (1873) \\
\hline & Sweden & 1993M1 & - Price-level Targeting (1931-1937) \\
\hline & & & - Fixed Exchange Rate Regime (1970) \\
\hline & Finland & 1993M2 & - Fixed exchange rate regime (1970) \\
\hline & & & - Mixed system during transition (1981-1985) \\
\hline & South Africa & 2000M2 & $\begin{array}{l}\text { - Monetary Aggregates (Cost of cash reserves-based system with pre-announced } \\
\text { monetary targets (M3)) (1986-1998) }\end{array}$ \\
\hline \multirow{6}{*}{ Developing } & Brazil & 1999M6 & - Fixed Exchange Rate Regime (1970) \\
\hline & Colombia & 1999M9 & - Fixed Exchange Rates Regime (1973) \\
\hline & Philippines & 2002M1 & - Monetary Aggregates (before 2002) \\
\hline & Poland & 1998M10 & - Fixed Exchange Rate Regime (1990) \\
\hline & Thailand & 2000M5 & - Pegged/ Fixed Exchange Rate Regime (Second World War - June 1997) \\
\hline & & & - Monetary Aggregates /Targeting Regime (July 1997 - May 2000) \\
\hline
\end{tabular}

For the background study, we review earlier monetary policies that have been adopted by the sample countries in Table 1. Among the developed countries, United Kingdom is the first to adopt the IT policy. According to Guender and Oh (2006), Sweden is the second country among the developed countries to adopt IT. As in U.K., Sweden also had undergone the Gold Standard policy in 1873 (Fregert and Jonung, 1998). In particular, Sweden was the only country in the world to adopt the Price-level Targeting during September 1931 until 1937 (the outbreak of World War II).

In general for developed countries, the Fixed Exchange Rate regimes ended up as the last monetary policy before the IT adoption except for Korea. Korea was applying the Monetary Aggregates for M1 during 1976, M2 at the mid of 1990, M2 and MCT for 1997.

On the other hand, as in Table 1, most of the developing countries end up applying the Fixed Exchange Rate regime such as Poland, Colombia and Brazil before adopting IT. Furthermore, Thailand and Philippines same as South Africa had adopted the Monetary Aggregates Policy before the introduction of IT regime.

As we can see in Table 1, the starting dates for the developed countries to adopt both Fixed Exchange rate and Monetary Aggregates regime are slightly later than the developed countries. Nevertheless, the initial date of IT adoption for the developed countries is earlier than the developing countries. We can observe that the developed countries tend to follow the footstep of the developed in refining their monetary policy. Then, arguments have arisen as to whether the developed countries can outperform the developed countries under the same regime or vice versa.

\section{Methodology and Data Analysis}

\subsection{Techniques}

\subsubsection{Ordinary Least Squares Approach (OLS)}

Ordinary least squares (OLS) is a method used in statistics and econometrics, for the unknown parameters estimation in a linear regression model. The sum of squared vertical distances between the observed responses in the dataset, and the responses predicted by the linear approximation is minimized by this method. The resulting estimator can be expressed by a simple formula, especially in the case of a single regressor on the right-hand side. In this study, we use the OLS to investigate the "within-country" variation, that is, to ask whether a country is more likely to have lower inflation if it adopts the IT framework, we work with the following single Equation (1):

$$
\begin{gathered}
X_{t}=\alpha+\beta \cdot X_{t-1}+\gamma \cdot I T_{t} \\
\pi_{t}^{d}=\pi-\pi_{t}^{m} \\
g a p=y-y^{h p}
\end{gathered}
$$


where $X_{t}$ is a macroeconomic performance indicator such as inflation rate $(\pi)$, exchange rate (er), output growth $(y)$, the deviation of inflation $\left(\pi^{d}\right)$ and the output gap (gap). The lagged value $X_{t-1}$ is included to capture persistence and mean-reverting dynamics, but reduces the dependent variable sample to $(T-1)$ time observations as a consequence. The model includes lagged own $X_{t-1}$ to account for a possible bias due to potential correlation between the dummy variable and past inflation performance, i.e. if high inflation countries are more likely to adopt IT.

However, our focus will be on the IT dummy variable $I T_{t}$, equal to 1 if the country is inflation targeted in period $\mathrm{t}$ and 0 otherwise. Thus, $I T_{t}$ is the treatment variable. $I T_{t}$ measures the average effect of the IT across all targeting countries. $\alpha, \beta$ and $\gamma$ are the constant coefficients at time $t$, coefficient on $t-1$ period and coefficient of the IT dummy at time $t$, respectively.

From equation (2), $\pi^{d}$ is the deviation of inflation where we obtained the differences between the real inflation $(\pi)$ and the average value of inflation $\left(\pi^{m}\right)$. As we divided the period of IT implementation into pre and post, thus we have two inflation mean values. $\pi_{1}^{m}$ and $\pi_{2}^{m}$ are the pre-average mean and post-average mean of inflation rate, respectively. Thus, $I T_{t}$ is excluded in equation (1) when the sub-sample data is applied.

From Equation (3), the output gap (gap) is the difference between actual output and potential output. The actual output is proxied by IPI and the potential output is proxied by the filtered IPI $\left(y^{h p}\right)$.

Hodrick-Prescott Filter (Hp-filter) helps to separate the cyclical component of a time series from raw data. Yet, it smooth non-linear representation of a time series and more sensitive to long term than short term fluctuations by modifying a multiplier, $\lambda$ (Razzak and Dennis, 1999).

Further testing is on the trade-off relation between the deviation inflation and output gap is carried out by the following equation:

$$
\pi_{t}^{d}=\lambda_{0}+\lambda_{1} g a p_{t}
$$

Equation (4) is testing the relationship between the deviation of inflation and the output gap. $\lambda_{0}$ and $\lambda_{1}$ are the intercepts and coefficients of the variables.

\subsubsection{Panel Data Analysis}

In statistics and econometrics, the term panel data refers to multi-dimensional data. Panel data analysis, also known as cross-sectional time-series analysis, looks at a group of people, the 'panel,' on more than one occasion (Curran, 2010). According to Schmidheiny (2010), in panel data, individuals (persons, countries ...) are observed at several points in time (days, years, before and after treatment ...). They are more informative in the sense of more variability, less collinearity and more degrees of freedom. Besides, panel data estimates are more efficient where allow to study individual dynamics (e.g. separating IT adoption period in this study and cohort effects) (Bruderl, 2005).

In general, the multiple linear regression model for individual $i=1, \ldots, N$ who is observed at period $t=1, \ldots, \mathrm{T}$ is given by:

$$
y_{i t}=\alpha+x_{i t}^{\prime} \beta+c_{i}+u_{i t}
$$

where $y_{i t}$ is a dependent variable, $x_{i t}^{\prime}$ is a $\mathrm{K}$-dimensional row vector of explanatory variables excluding the constant, $\alpha$ is the intercept, $\beta$ is a K-dimensional column vector of parameters, $c_{i}$ is an individual-specific effect and $u_{i t}$ is an error term.

The $T$ observations for individual $i$ can be expressed as below:

$$
y_{i}=\left[\begin{array}{c}
y_{i 1} \\
\vdots \\
y_{i t} \\
\vdots \\
y_{i T}
\end{array}\right]_{T \times 1} \quad X_{i}=\left[\begin{array}{c}
x_{i 1}^{\prime} \\
\vdots \\
x_{i t}^{\prime} \\
\vdots \\
x_{i T}^{\prime}
\end{array}\right]_{T \times K} \quad u_{i}=\left[\begin{array}{c}
u_{i 1} \\
\vdots \\
u_{i t} \\
\vdots \\
u_{i T}
\end{array}\right]_{T \times 1}
$$

and $N T$ observations for all individuals and time period:

$$
y=\left[\begin{array}{c}
y_{1} \\
\vdots \\
y_{i} \\
\vdots \\
y_{N}
\end{array}\right]_{N T \times 1} \quad X=\left[\begin{array}{c}
x_{1} \\
\vdots \\
x_{i} \\
\vdots \\
x_{N}^{\prime}
\end{array}\right]_{N T \times K} \quad u=\left[\begin{array}{c}
u_{1} \\
\vdots \\
u_{i} \\
\vdots \\
u_{N}
\end{array}\right]_{N T \times 1} .
$$


According to Schmidheiny (2010), a fixed effect model is used to examine the reasons of changes within an entity (individual- specific effect) which is a random variable that is allowed to be correlated with the explanatory variables. The fixed effects model controls all time-invariant differences between the individuals. Fixed-effects models have unbiased estimated coefficients because the time-invariant characteristics is omitted from this model. According to Oscar (2010), those time-invariant characteristics are unique and uncorrelated with other individual characteristics.

According to Oscar (2010), a general fixed effects model of panel data is:

$$
y_{i t}=\beta x_{i t}+\alpha_{i}+u_{i t}
$$

where $y_{i t}$ is the dependent variable where $i=$ entity and $t=$ time. $\propto_{i}, i=1, \ldots, \mathrm{n}$ is the unknown intercept for each entity ( $n$ entity-specific intercepts). $x_{i t}$ represents one independent variable, $u_{i t}$ is the error term. $E\left(u_{i t}\right)=0$ and $\operatorname{Var}\left(u_{i t}\right)=\sigma_{y}$. The fixed effects estimator of the slope coefficient $\beta$ estimates the model by OLS:

$$
\hat{\beta}=\left(X^{\prime} X\right)^{-1} X^{\prime} y
$$

The fixed effect estimator is unprejudiced in small samples. This estimator is steady and asymptotically normally distributed once the amount of individual converges to infinity (Nelson (2011). When we suspect that there are time-specific effects $\delta_{t}$ which affect all the individuals in the same way:

$$
y_{i t}=\beta x_{i t}+\alpha_{i}+u_{i t}+\delta_{t}
$$

Besides, we can also estimate this extended model by including a dummy variable for each time period. By assuming a fixed number of time periods $\mathrm{T}$ and the number of individuals $\mathrm{N}$, fixed effect estimator is consistent using time dummy variable as above.

In this study, we know that the IT adoption period for each country is different. Hence, our data are unbalanced panel data. We use fixed effect model due to the time-specific effect. This is an evaluation of IT treatment approach toward the dependent variable.

In our test, we have modified the Equation (5) into a common panel data regression model represented by dependent variable $X_{n, t}$ and one independent variable $X_{n, t-1} . I T_{n, t}$ and $\delta_{t}$ are added. It can be written as

$$
X_{n, t}=\alpha+\beta X_{n, t-1}+\gamma I T_{n, t}+\delta_{n, t}
$$

where $X_{n, t}$ is a macroeconomic performance indicator such as inflation rate $(\pi)$, output growth $(y)$ and exchange rate (er); the subscript $\mathrm{n}_{1}=1,2,3,4,5$ is the developed countries group and $\mathrm{n}_{2}=1,2,3,4,5,6$ is the developing countries group. $\mathrm{t}$ is the period. $\alpha$ and $\beta$ are intercept and coefficients of $X_{n, t-1}, \delta$ is the fixed effect. $I T_{n, t}$ is the time dummy where IT is adopted.

To be more rigorous, there will be 3 panel data evaluations based on the 3 indicators: $\pi$, er and $y$; tested on 3 classified sample groups: 1 . All of the 11 countries both developing and developed countries, 2. Five developed and lastly is the 3 . Six developing countries. These evaluations is to judge the performance of the IT framework in vary types of country.

\section{Results}

In this section, the main findings can be divided into three partitions:

\subsection{Comparing the Impact of IT between Pre and Post-IT Period by OLS}

\subsubsection{The Impacts of IT on Inflation Rate $(\pi)$}

The estimated results of Equation (1) are summarized in Table 2

$\beta$ measures the persistency of inflation rate and $\gamma$ indicates the impact of IT. The persistency of inflation for each country ranges from 0.12 to 0.92 . Brazil has the highest value of $\beta$ which is 0.916345 . This indicates that Brazil has a very high and persistent inflation throughout year 1980 until year 2010. Yet, we also observe that Sweden has the lowest persistence value. Its $\beta$ is just 0.120894 .

The estimated coefficient of the IT dummy, $\gamma$ is significantly negative in all the listed countries in the sample. The results indicates that implementation of IT is able to reduce the persistency in inflation. Poland has the highest value of $\gamma$, that is -0.014379 . This indicates that during the adoption of IT, Poland has significantly reduced $1.44 \%$ in inflation rate in Poland. Besides, Thailand shows the smallest value in $\gamma,-0.001169$. We found that country with higher and more persistency in inflation experience larger reduction in the persistency of inflation compared to countries with lower inflation rate. This means that IT leads to higher gain/improvement in inflation in countries with higher inflation rate. 
Based on the results obtained, we have noted that the inflation rate of all of the tested countries is affected significantly after the implementation of IT. IT has helped in lowering the inflation rate of all the tested countries.

Table 2. Results for Inflation rate OLS testing

\begin{tabular}{|c|c|c|c|c|c|}
\hline \multirow{2}{*}{ Country } & \multicolumn{3}{|c|}{$\begin{array}{c}\text { Coefficient } \\
\text { (Standard Error) }\end{array}$} & \multirow{2}{*}{$R^{2}$} & \multirow{2}{*}{$\begin{array}{l}\text { Durbin-Watson } \\
\text { stat }\end{array}$} \\
\hline & $\alpha$ & $\beta$ & $\gamma$ & & \\
\hline Korea & $\begin{array}{l}0.002692 * * * \\
(0.000408)\end{array}$ & $\begin{array}{l}0.433493 * * * \\
(0.044201)\end{array}$ & $\begin{array}{l}-0.001211^{* *} \\
(0.00061)\end{array}$ & 0.231332 & 2.081358 \\
\hline Spain & $\begin{array}{l}0.005017 * * * \\
(0.000489)\end{array}$ & $\begin{array}{c}0.228495 * * * \\
(0.050843)\end{array}$ & $\begin{array}{l}-0.003187 * * * \\
(0.000542)\end{array}$ & 0.195587 & 1.987310 \\
\hline United kingdom & $\begin{array}{l}0.004026 * * * \\
(0.000465)\end{array}$ & $\begin{array}{l}0.229849 * * * \\
(0.050616)\end{array}$ & $\begin{array}{l}-0.002286 * * * \\
(0.000516)\end{array}$ & 0.135776 & 2.026039 \\
\hline Sweden & $\begin{array}{l}0.005058 * * * \\
(0.000513)\end{array}$ & $\begin{array}{r}0.120894 * * \\
(0.051692)\end{array}$ & $\begin{array}{l}-0.003944 * * * \\
(0.000593)\end{array}$ & 0.167501 & 1.998630 \\
\hline Finland & $\begin{array}{l}0.003963 * * * \\
(0.000393)\end{array}$ & $\begin{array}{c}0.214336^{* * *} \\
(0.050345)\end{array}$ & $\begin{array}{l}-0.002983 * * * \\
(0.000435)\end{array}$ & 0.234709 & 2.034340 \\
\hline South Africa & $\begin{array}{l}0.006816^{* * *} \\
(0.000573)\end{array}$ & $\begin{array}{l}0.243998 * * * \\
(0.050466)\end{array}$ & $\begin{array}{l}-0.003274 * * * \\
(0.000683)\end{array}$ & 0.153476 & 2.108060 \\
\hline Brazil & $\begin{array}{l}0.009214 * * * \\
(0.003309)\end{array}$ & $\begin{array}{c}0.916345^{* * *} \\
(0.021073)\end{array}$ & $\begin{array}{l}-0.008743 * * \\
(0.004395)\end{array}$ & 0.880015 & 1.692748 \\
\hline Colombia & $\begin{array}{l}0.006068 * * * \\
(0.00079)\end{array}$ & $\begin{array}{c}0.641316^{* * *} \\
(0.040207)\end{array}$ & $\begin{array}{l}-0.004403 * * * \\
(0.000822)\end{array}$ & 0.103804 & 1.716094 \\
\hline Philippines & $\begin{array}{l}0.003257 * * * \\
(0.000602)\end{array}$ & $\begin{array}{c}0.608453 * * * \\
(0.041448)\end{array}$ & $\begin{array}{l}-0.001649 * \\
(0.000926)\end{array}$ & 0.393228 & 1.976235 \\
\hline Poland & $\begin{array}{l}0.015513 * * * \\
(0.004132)\end{array}$ & $\begin{array}{l}0.625843^{* * *} \\
(0.046759)\end{array}$ & $\begin{array}{l}-0.014379 * * * \\
(0.005242)\end{array}$ & 0.477656 & 2.232310 \\
\hline Thailand & $\begin{array}{l}0.002716^{* * *} \\
(0.000409)\end{array}$ & $\begin{array}{l}0.276874 * * * \\
(0.048907)\end{array}$ & $\begin{array}{l}-0.001169^{*} \\
(0.00062)\end{array}$ & 0.097351 & 2.033105 \\
\hline
\end{tabular}

Note: *** represents $1 \%$ significance level

** represents $5 \%$ significance level

* represents $10 \%$ significance level

\subsubsection{The Impacts of IT on Output Growth $\left(y_{t}\right)$}

The estimated results of Equation (1) are summarized in Table 3.

We noted that almost all the coefficients, $\alpha, \beta$ and $\gamma$ are positive significant under the $1 \%, 5 \%$ and $10 \%$ significance level. However, the $\gamma$ for Korea and Philippines are positive but not significant under the stated level.

The estimated coefficients of the IT dummy $\gamma$ are significantly positive and take the range of 1 to 16 . These indicate that there is a very dramatic increase in output after the adoption of IT especially for Spain and Sweden. The adoption of IT brings improvement in output by 15.96246 and 11.54870 units respectively in these two economies. Furthermore, the standard error of $\gamma$ for each and every country is small. 
Table 3. Results for output growth OLS testing

\begin{tabular}{|c|c|c|c|c|c|}
\hline \multirow{2}{*}{ Country } & \multicolumn{3}{|c|}{ Coefficient (Standard Error) } & \multirow{2}{*}{$R^{2}$} & \multirow{2}{*}{$\begin{array}{c}\text { Durbin-Watson } \\
\text { stat }\end{array}$} \\
\hline & $\alpha$ & $\beta$ & $\gamma$ & & \\
\hline \multirow{2}{*}{ Korea } & $0.824223^{*}$ & $0.983397^{* * *}$ & 1.483249 & \multirow{2}{*}{0.987475} & \multirow{2}{*}{2.559314} \\
\hline & $(0.479892)$ & $(0.011788)$ & $(0.940114)$ & & \\
\hline \multirow{2}{*}{ Spain } & $54.13987 * * *$ & $0.250445 * * *$ & $15.96246 * * *$ & \multirow{2}{*}{0.492931} & \multirow{2}{*}{2.074391} \\
\hline & $(3.740214)$ & $(0.050528)$ & $(1.592443)$ & & \\
\hline \multirow{2}{*}{ United kingdom } & $31.39662 * * *$ & $0.617282 * * *$ & $6.212457 * * *$ & \multirow{2}{*}{0.714152} & \multirow{2}{*}{2.124308} \\
\hline & $(3.394313)$ & $(0.041047)$ & $(0.912265)$ & & \\
\hline \multirow{2}{*}{ Sweden } & $39.41595 * * *$ & $0.435748^{* * *}$ & $11.54870^{* * *}$ & \multirow{2}{*}{0.469052} & \multirow{2}{*}{2.119049} \\
\hline & $(3.426610)$ & $(0.046979)$ & $(1.637154)$ & & \\
\hline \multirow{2}{*}{ Finland } & $6.839828 * * *$ & $0.861182 * * *$ & $5.645084 * * *$ & \multirow{2}{*}{0.904681} & \multirow{2}{*}{2.346193} \\
\hline & $(1.407046)$ & $(0.025900)$ & $(1.294125)$ & & \\
\hline \multirow{2}{*}{ South Africa } & $3.860645^{* * *}$ & $0.952560 * * *$ & $1.001501 * *$ & \multirow{2}{*}{0.971424} & \multirow{2}{*}{2.661021} \\
\hline & $(1.299224)$ & $(0.016325)$ & $(0.420952)$ & & \\
\hline \multirow{2}{*}{ Brazil } & $2.141679 * *$ & $0.973712 * * *$ & $0.676214 *$ & \multirow{2}{*}{0.981441} & \multirow{2}{*}{1.936911} \\
\hline & $(1.071656)$ & $(0.013924)$ & $(0.404900)$ & & \\
\hline \multirow{2}{*}{ Colombia } & $8.882120 * * *$ & $0.899317 * * *$ & $2.021533 * *$ & \multirow{2}{*}{0.853999} & \multirow{2}{*}{2.292747} \\
\hline & $(2.200337)$ & $(0.024744)$ & $(0.950190)$ & & \\
\hline \multirow{2}{*}{ Philippines } & $0.813014 *$ & $0.983402 * * *$ & 1.013411 & \multirow{2}{*}{0.986161} & \multirow{2}{*}{2.336392} \\
\hline & $(0.429650)$ & $(0.010834)$ & $(0.789726)$ & & \\
\hline \multirow{2}{*}{ Poland } & $2.81203 * *$ & $0.950565 * * *$ & $2.530523 * *$ & \multirow{2}{*}{0.960766} & \multirow{2}{*}{2.492602} \\
\hline & $(1.112241)$ & $(0.018606)$ & $(1.036248)$ & & \\
\hline Thailand & $2.903134 * *$ & $0.961314 * * *$ & $3.84982 * *$ & 0.978265 & 2864710 \\
\hline & $(1.233075)$ & $(0.016559)$ & (1.660517) & 0.918265 & \\
\hline
\end{tabular}

Note: $* * *$ represents $1 \%$ significance level

** represents $5 \%$ significance level

* represents $10 \%$ significance level

\subsubsection{The Impacts of Exchange Rate Volatility (er)}

The estimated results of Equation (1) are summarized in Table 4.

The estimated persistence parameters $\beta$, as presented in Table 3.3, fall in the range between 0.96 and 0.99 and are positive significance under the $1 \%$ significance level. Its standard errors are all very small and almost close to zero. This indicates that the exchange rate is highly persistent. The IT dummy $\gamma$ is significant in Brazil and Colombia only.

As a hyperinflation country, Brazil has 0.999525 for its R-square. It is the highest among the others. Nevertheless, the adoption of IT has significantly increased the exchange rate in Brazil. The increase in exchange rate denotes the NEER appreciation in exchange rate.

Colombia has the second highest R-square compared to other countries, 0.998883 . The application of IT policy in Colombia also induces greater volatility in exchange rate or the appreciation of 0.787001 units. In other cases, the implementation of IT does not lead to significant impact on the volatility of exchange rate.

Different results are obtained in OLS testing on er. There is weak evidence that IT led to higher volatility in exchange rate as the coefficients of the IT dummy, $\gamma$ are not significant. Exchange rate volatility is not influenced by the IT regime. 
Table 4. Results for exchange rate volatility OLS testing

\begin{tabular}{|c|c|c|c|c|c|}
\hline \multirow[t]{2}{*}{ Country } & \multicolumn{3}{|c|}{$\begin{array}{c}\text { Coefficient } \\
\text { (Standard Error) }\end{array}$} & \multirow[t]{2}{*}{$R^{2}$} & \multirow[t]{2}{*}{ Durbin-Watson stat } \\
\hline & $\alpha$ & $\beta$ & $\gamma$ & & \\
\hline Korea & $\begin{array}{c}1.081033 \\
(0.848515)\end{array}$ & $\begin{array}{c}0.989108^{* * *} \\
(0.005875)\end{array}$ & $\begin{array}{c}-0.17966 \\
(0.424975)\end{array}$ & 0.992945 & 1.109462 \\
\hline Spain & $\begin{array}{c}1.858146^{* *} \\
(0.76915)\end{array}$ & $\begin{array}{c}0.981871^{* * * *} \\
(0.006726)\end{array}$ & $\begin{array}{c}-0.05463 \\
(0.151352)\end{array}$ & 0.98915 & 1.268174 \\
\hline United kingdom & $\begin{array}{c}1.142863 \\
(1.082394)\end{array}$ & $\begin{array}{c}0.98792 * * * \\
(0.010328)\end{array}$ & $\begin{array}{c}-0.07514 \\
(0.202323)\end{array}$ & 0.970554 & 1.358220 \\
\hline Sweden & $\begin{array}{c}2.469214 * * \\
(1.17303)\end{array}$ & $\begin{array}{c}0.979078 * * * \\
(0.008551)\end{array}$ & $\begin{array}{l}-0.40381 \\
(0.35779)\end{array}$ & 0.992643 & 1.295693 \\
\hline Finland & $\begin{array}{c}0.559822 \\
(1.207968)\end{array}$ & $\begin{array}{c}0.993572 * * * \\
(0.011188)\end{array}$ & $\begin{array}{c}0.131747 \\
(0.179842)\end{array}$ & 0.976659 & 1.578149 \\
\hline South Africa & $\begin{array}{c}-0.58957 \\
(0.938045)\end{array}$ & $\begin{array}{c}0.994528 * * * \\
(0.002753)\end{array}$ & $\begin{array}{c}1.218681 \\
(1.117186)\end{array}$ & 0.997844 & 1.409328 \\
\hline Brazil & $\begin{array}{c}-4.87 \mathrm{E}+09 * * * \\
(1.63 \mathrm{E}+09)\end{array}$ & $\begin{array}{c}0.965619 * * * \\
(0.001137)\end{array}$ & $\begin{array}{l}4.87 \mathrm{E}+09 * \\
(2.52 \mathrm{E}+09)\end{array}$ & 0.999525 & 1.113490 \\
\hline Colombia & $\begin{array}{c}-0.06489 \\
(0.625795)\end{array}$ & $\begin{array}{c}0.99309 * * * \\
(0.002092)\end{array}$ & $\begin{array}{c}0.787001^{* *} \\
(0.601754)\end{array}$ & 0.998883 & 1.391403 \\
\hline Philippines & $\begin{array}{c}0.774173 \\
(0.991944)\end{array}$ & $\begin{array}{c}0.989841^{* * *} \\
(0.003246)\end{array}$ & $\begin{array}{c}0.245973 \\
(1.066672)\end{array}$ & 0.996923 & 1.745143 \\
\hline Poland & $\begin{array}{c}-66.5336 \\
(63.95647)\end{array}$ & $\begin{array}{c}0.990788^{* * *} \\
(0.003475)\end{array}$ & $\begin{array}{c}67.50007 \\
(88.11137)\end{array}$ & 0.996430 & 2.062413 \\
\hline Thailand & $\begin{array}{c}2.844809 \\
(2.132366)\end{array}$ & $\begin{array}{c}0.974011^{* * *} \\
(0.016589)\end{array}$ & $\begin{array}{c}-0.03819 \\
(0.530635)\end{array}$ & 0.968775 & 1.276161 \\
\hline
\end{tabular}

Note: $* * *$ represents $1 \%$ significance level

** represents $5 \%$ significance level

* represents $10 \%$ significance level

\subsubsection{The Impacts of IT on Deviation of Inflation $\left(\pi^{\mathrm{d}}\right)$}

The estimated results of Equation (1) are summarized in Table 5 and 6.

The persistency of deviation in inflation is estimated to fall between ranges from 0.16 to 0.92 during the pre-IT period. They are between 0.13 and 0.71 during the post-IT period. Both pre-IT and post-IT period are statistically significant in $\beta$. Although the result of $\beta$ for Sweden is not significant before the IT implementation, it is significant after the implementation of IT.

Besides, there are six out of eleven countries which experience smaller coefficient $\beta$ during the post-IT period than the pre-IT period. These countries are Korea, U.K., Finland, Brazil, Philippines and Poland. In other words, the persistency in $\pi_{t}^{d}$ in these countries has declined in the post-crisis period and the deviation in inflation is likely to decline over time.

The obtained results are mixed where a few countries have their deviation of inflation slightly increased after the implementation of IT. 
Table 5. Results for Pre-IT deviation of inflation $\left(\pi_{1}{ }^{\mathrm{d}}\right)$ OLS testing

\begin{tabular}{|c|c|c|c|c|}
\hline \multirow{2}{*}{ Country } & \multicolumn{2}{|c|}{ Coefficient (Standard Error) } & \multirow{2}{*}{$R^{2}$} & \multirow{2}{*}{ Durbin-Watson sta } \\
\hline & $\alpha$ & $\beta$ & & \\
\hline Korea & $\begin{array}{c}0.002853 * * * \\
(0.000522)\end{array}$ & $\begin{array}{c}0.452424 * * * \\
(0.056373)\end{array}$ & 0.230522 & 2.125764 \\
\hline Spain & $\begin{array}{c}0.005153 * * * \\
(0.00062)\end{array}$ & $\begin{array}{c}0.203332 * * * \\
(0.073778)\end{array}$ & 0.041371 & 2.03301 \\
\hline United kingdom & $\begin{array}{c}0.003656 * * * \\
(0.000604)\end{array}$ & $\begin{array}{c}0.294891 * * * \\
(0.077595)\end{array}$ & 0.088366 & 2.048121 \\
\hline Sweden & $\begin{array}{c}0.005292 * * * \\
(1.17303)\end{array}$ & $\begin{array}{c}0.074928 \\
(0.008551)\end{array}$ & 0.005683 & 2.003048 \\
\hline Finland & $\begin{array}{c}0.003683 * * * \\
(0.000527)\end{array}$ & $\begin{array}{c}0.26474 * * * \\
(0.07711)\end{array}$ & 0.071531 & 2.068584 \\
\hline South Africa & $\begin{array}{c}0.00781 * * * \\
(0.000717)\end{array}$ & $\begin{array}{c}0.167845^{* * *} \\
(0.064049)\end{array}$ & 0.02816 & 2.07028 \\
\hline Brazil & $\begin{array}{l}0.009147 * * \\
(0.004164)\end{array}$ & $\begin{array}{c}0.916599 * * * \\
(0.02664)\end{array}$ & 0.837913 & 1.690955 \\
\hline Colombia & $\begin{array}{c}0.006177 * * * \\
(0.000983)\end{array}$ & $\begin{array}{c}0.633322 * * * \\
(0.051026)\end{array}$ & 0.399042 & 1.732994 \\
\hline Philippines & $\begin{array}{c}0.003199 * * * \\
(0.000693)\end{array}$ & $\begin{array}{c}0.613961^{* * *} \\
(0.048982)\end{array}$ & 0.376662 & 1.971806 \\
\hline Poland & $\begin{array}{l}0.015416 * * \\
(0.006045)\end{array}$ & $\begin{array}{c}0.626474 * * * \\
(0.068801)\end{array}$ & 0.398783 & 2.233925 \\
\hline Thailand & $\begin{array}{c}0.002821 * * * \\
(0.000432)\end{array}$ & $\begin{array}{c}0.246984 * * * \\
(0.060351)\end{array}$ & 0.065233 & 2.032425 \\
\hline
\end{tabular}

Note: ${ }^{* * *}$ represents $1 \%$ significance level

** represents $5 \%$ significance level

* represents $10 \%$ significance level 
Table 6. Results for Post-IT deviation of inflation $\left(\pi_{2}{ }^{d}\right)$ OLS testing

\begin{tabular}{|c|c|c|c|c|}
\hline \multirow{2}{*}{ Country } & \multicolumn{2}{|c|}{ Coefficient (Standard Error) } & \multirow{2}{*}{$R^{2}$} & \multirow{2}{*}{ Durbin-Watson stat } \\
\hline & $\alpha$ & $\beta$ & & \\
\hline Korea & $\begin{array}{c}0.001741 * * * \\
(0.000367)\end{array}$ & $\begin{array}{c}0.248357 * * * \\
(0.079296)\end{array}$ & 0.061383 & 1.826023 \\
\hline Spain & $\begin{array}{c}0.001711^{* * *} \\
(0.000348)\end{array}$ & $\begin{array}{c}0.258516^{* * *} \\
(0.069785)\end{array}$ & 0.067693 & 1.892076 \\
\hline United kingdom & $\begin{array}{c}0.001939 * * * \\
(0.000307\end{array}$ & $\begin{array}{c}0.134835^{* *} \\
(0.067631)\end{array}$ & 0.018069 & 1.988765 \\
\hline Sweden & $\begin{array}{c}0.00093 * * * \\
(0.000275)\end{array}$ & $\begin{array}{c}0.17601 * * * \\
(0.062222)\end{array}$ & 0.036206 & 1.861848 \\
\hline Finland & $\begin{array}{c}0.001076 * * * \\
(0.000225)\end{array}$ & $\begin{array}{l}0.132528 * \\
(0.068325)\end{array}$ & 0.017438 & 1.978823 \\
\hline South Africa & $\begin{array}{c}0.003023 * * * \\
(0.000553)\end{array}$ & $\begin{array}{c}0.370147^{* * *} \\
(0.081304)\end{array}$ & 0.13936 & 1.99922 \\
\hline Brazil & $\begin{array}{c}0.001996^{* * *} \\
(0.00045)\end{array}$ & $\begin{array}{l}0.63162 * * * \\
(0.066221)\end{array}$ & 0.400814 & 1.843596 \\
\hline Colombia & $\begin{array}{c}0.001395^{* * *} \\
(0.000397)\end{array}$ & $\begin{array}{c}0.700811 * * * \\
(0.061842)\end{array}$ & 0.491238 & 1.543397 \\
\hline Philippines & $\begin{array}{c}0.001907 * * * \\
(0.000511)\end{array}$ & $\begin{array}{c}0.529547^{* * *} \\
(0.08282)\end{array}$ & 0.280242 & 1.991122 \\
\hline Poland & $\begin{array}{c}0.001666 * * * \\
(0.000387)\end{array}$ & $\begin{array}{c}0.449163 * * * \\
(0.074308)\end{array}$ & 0.202381 & 1.926724 \\
\hline Thailand & $\begin{array}{c}0.001403 * * * \\
(0.000523)\end{array}$ & $\begin{array}{c}0.337172 * * * \\
(0.084199)\end{array}$ & 0.113699 & 2.032637 \\
\hline
\end{tabular}

Note: $* * *$ represents $1 \%$ significance level

** represents $5 \%$ significance level

* represents $10 \%$ significance level

\subsubsection{The Impacts of IT on Output Gap (gap)}

The estimated results of Equation (1) are summarized in Table 7.

The persistency of the output gap is estimated by the $\beta$ parameter. We notice that all the coefficients of $\beta$ are significant at least under the 5\% significance level except Sweden. Spain has the smallest value in $\beta,-0.12113$. This indicates that the persistency of its output gap leads to the decline in current output gap.

The estimated coefficient is significant under the $1 \%$ and $5 \%$ significance level for the pre-IT and post-IT adoption period in Colombia. From Table 4.6, coefficient $\beta$ for Colombia has reduced. This indicates that the gap between the real output and the potential output is smaller after the IT implementation. The implementation of IT has no significance impact on the output gap in all countries as the estimated coefficients of the IT, $\gamma$ are not significant under any stated level. Once the $\gamma$ is not significant, then the changes on output gap are not due to the implementation of IT. 
Table 7. Results of output gap OLS testing

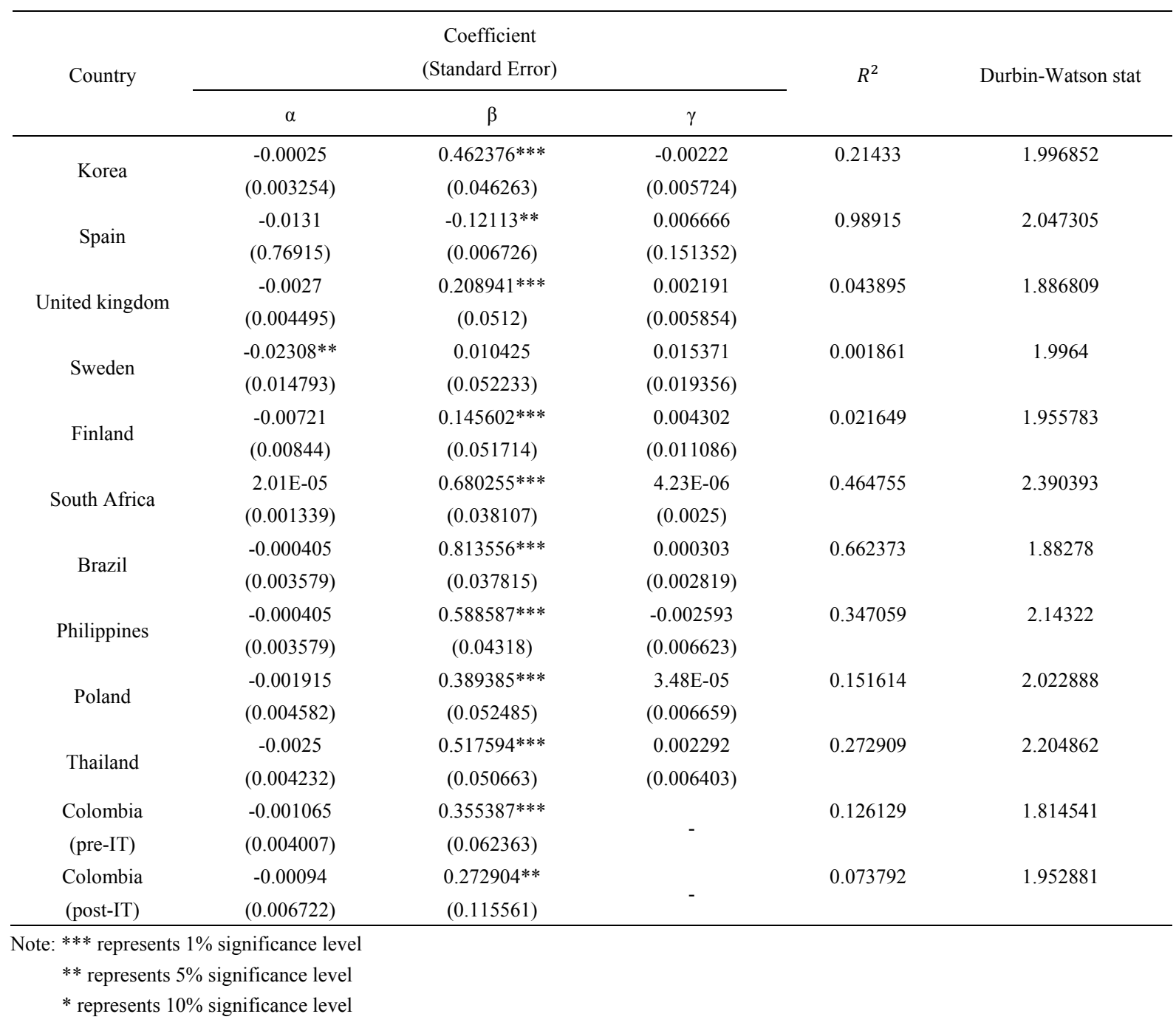

3.2 Comparing the Performance if IT between Developing versus Developed Economies by Panel Data Analysis From Equation (6), we work out equation for inflation rate $(\pi)$, output growth $(y)$ and exchange $(e r)$ :

$$
\begin{gathered}
\pi_{n, t}=\alpha+\beta \cdot \pi_{n, t-1}+\gamma I T_{n, t}+\delta_{t} \\
y_{n, t}=\alpha+\beta \cdot y_{n, t-1}+\gamma I T_{n, t}+\delta_{t} \\
\log e r_{n, t}=\alpha+\beta \cdot \log e r_{n, t-1}+\gamma I T_{n, t}+\delta_{t}
\end{gathered}
$$

where $\pi_{n, t}$ is inflation rate, $y_{n, t}$ is IPI and $e r_{n, t}$ is exchange rate; the subscript $n=1,2,3, \ldots, N$ is the country involved. There are three groups of countries:

1. Overall (11 developed and developing countries)

2. The 5 developed countries

3. The 6 developing countries.

$t$ is the period, $\alpha$ and $\beta$ are coefficients, and $\delta$ is the fixed effect. These panel data evaluations are testing the effectiveness of the IT framework in various types of country. 
Table 8. Panel Data Analysis of inflation rate $(\pi)$

\begin{tabular}{lcc}
\hline & Coefficient & Standard Error \\
\hline All 11 countries & & 0.001009 \\
\hline$\alpha$ & $0.002505 * *$ & 0.062595 \\
$\beta$ & $0.869781^{* * *}$ & 0.000942 \\
$\gamma$ & $-0.002061 * *$ & - \\
Durbin Watson Statistic & 2.16154 & - \\
R-squared & 0.827308 & 0.000425 \\
\hline Developed & & 0.058553 \\
$\alpha$ & $0.00405 * * *$ & 0.000406 \\
$\beta$ & $0.268341 * * *$ & - \\
$\gamma$ & $-0.002655 * * *$ & - \\
Durbin Watson Statistic & 2.041043 & 0.001565 \\
R-squared & 0.191091 & 0.060816 \\
\hline Developing & & 0.001702 \\
\hline$\alpha$ & $0.003817 * *$ & - \\
$\beta$ & $0.872087 * * *$ & - \\
\hline Durbin Watson Statistic & $-0.003526 * *$ & \\
R-squared & 2.137042 & \\
\hline Note: represents 10\% significance level & 0.827841 & \\
\hline Estimation based on Equation 7) & & \\
\hline
\end{tabular}

Table 8 shows 3 groups of IT adoption countries. We can see that $\alpha, \beta$ and $\gamma$ as the coefficients of the model are significant under the stated significance level for all the three groups of countries. We focus on the $\beta$ and $\gamma$ coefficients which show the persistency of inflation rate and whether the persistency is due to IT adoption or not.

The results indicate that the developing countries are more persistent in inflation rate than the developed countries. Both developed and developing countries managed to reduce the inflation rate after implementing the IT. However, developing countries show a larger reduction as their inflation rate is much higher than the developed countries. This model more fits with $82.78 \%$ for developing countries than the developed countries with $19.11 \%$.

As a conclusion for the 11 countries, their result for $\beta$ is 0.869781 , which means the persistency of inflation is still high. $\gamma$ equals to -0.002061 implies that the inflation rate due to IT implementation is 0.002061 less than before. The model fitted with $82.7 \%$. Standard error is close to zero. All the d-test is close to 3. Yet, we can say that the model is stable and less skewed.

Table 9 shows 3 groups of IT adoption countries. We can see that $\alpha, \beta$ and $\alpha$ as the coefficients of the model are significant under the stated significant level for all the three groups of countries except $\alpha$ of the developed country. We focus on the $\beta$ and $\gamma$ coefficients which show the persistency of output growth due to IT adoption.

This model fitted better in developing countries with $97.8 \%$ than the developed countries with $85.6 \%$. Persistency of IPI shown by the $\beta$, where the developing countries are also higher and tend to be more fluctuated than the developed countries. Both of the results for developed and developing countries for the d-test is not skewed. The implementation of IT is effective in generating higher output growth. IT tends to increase larger growth in developed economies than developing economies.

As a conclusion for the 11 countries, their panel data results show that each and every $\alpha, \beta$ and $\gamma$ are significant. Their result for $\beta$ is $0.907871, \gamma$ is 3.593375 , R-squared is 0.929426 and d-test is 2.618968 . This means that the persistency of output growth due to IT are likely to be 3.593375 more than before. This effect is considered stable and less skewed since the d-test value is close to 3 and standard error is close to zero. 
Table 9. Panel Data Analysis of output growth (y)

\begin{tabular}{lcc}
\hline & Coefficient & Standard Error \\
\hline All 11 countries & & 2.896128 \\
$\alpha$ & $5.838278 * *$ & 0.042964 \\
$\beta$ & $0.907871 * * *$ & 1.170304 \\
$\gamma$ & $3.593375^{* * *}$ & - \\
Durbin Watson Statistic & 2.618968 & - \\
R-squared & 0.929426 & 7.246274 \\
\hline Developed & & 0.1088 \\
$\alpha$ & 11.50653 & 2.20925 \\
$\beta$ & $0.807885 * * *$ & - \\
$\gamma$ & $6.311605 * * *$ & - \\
Durbin Watson Statistic & 2.517106 & 0.516751 \\
R-squared & 0.855632 & 0.007034 \\
Developing & & 0.353135 \\
$\alpha$ & $1.9767 * * *$ & - \\
$\beta$ & $0.972414 * * *$ & - \\
\hline
\end{tabular}

Note: $* * *$ represents $1 \%$ significance level

** represents $5 \%$ significance level

* represents $10 \%$ significance level

(Estimation based on Equation 8)

According to Table 10, $\alpha$ and $\beta$ are significant under $1 \%$ significance level for all the three groups of countries. However, $\gamma$ for developed country is not significant. The persistency of developed countries for exchange rate is estimated to be 0.452082 . Standard error for $\gamma$ is nearly close to zero. This model is considered fitted with $21 \%$. The IT dummy coefficient, $\gamma$ is not significant. Thus, the implementation of IT does not lead to greater volatility in exchange rate of the developed country.

For the developing countries, the persistency shown by $\beta$ is slightly smaller than the developed countries. The standard error is 0.0016 which is nearly zero. From its $\gamma$, we notice that the adoption of IT leads to greater volatility in exchange rate. This is because the exchange rates of developed countries are free-floating where the developing countries tend to managed their exchange rate under the IT policy.

For $\gamma$ coefficient, there is significant evidence supporting the persistency of exchange rate due to the IT implementation. This is because the results for $\gamma$ of all the 11 countries are significant under $1 \%$ significance level. Besides, the standard error of $\gamma$ for all the countries is closed to zero. This indicates that the result is good and the d-test is close to 3 .

As a conclusion for the 11 countries, evidence shows that the implementation of IT leads to greater volatility in exchange rate in the economies considered in the analysis. 
Table 10. Panel Data Analysis of exchange rate (er)

\begin{tabular}{lcc}
\hline & Coefficient & Standard Error \\
\hline All 11 countries & & 0.000175 \\
$\beta$ & $-0.001758^{* * *}$ & 0.000243 \\
$\gamma$ & $0.451806^{* * *}$ & 0.000402 \\
Durbin Watson Statistic & $0.001077^{* * *}$ & - \\
R-squared & 1.748826 & - \\
\hline Developed & 0.206206 & 0.000427 \\
$\alpha$ & & 0.000248 \\
$\beta$ & $-0.001779^{* * *}$ & 0.00079 \\
$\gamma$ & $0.452082^{* * *}$ & - \\
Durbin Watson Statistic & 0.000904 & - \\
R-squared & 1.748417 & 0.000276 \\
\hline Developing & 0.206119 & 0.0016 \\
\hline$\alpha$ & & 0.000775 \\
$\beta$ & $-0.006127^{* * *}$ & - \\
\hline
\end{tabular}

Note: $* * *$ represents $1 \%$ significance level

** represents $5 \%$ significance level

* represents $10 \%$ significance level

(Estimation based on Equation 9)

\subsection{Trade-off Relationship between Output Gap and Deviation of Inflation by OLS}

The estimated results of Equation (1) are summarized in Table 11 and 12.

From Tables 11 and 12, countries like United Kingdom, Finland and Philippines show positive significant in $\lambda_{1}$ during the pre-IT period. On the other hand, during the post-IT period, there are more countries showing positive significant for $\lambda_{1}$ such as Sweden, Finland, South Africa and Poland. These indicate that all of the countries mentioned above have trade-off relationship between their output gap and inflation rate after the IT-adoption.

It is observed from Table 3.10 that before the implementation of IT, the estimated coefficients of the output gap, $\lambda_{1}$ are significantly negative in two of the countries in the sample - Brazil and Colombia. These indicate that there is a decline in inflation rate and increment in output growth for Brazil and Colombia. However, for the period of post-IT, only Colombia remains significantly negative while Brazil becomes positive non-significant. In other words, Brazil has the trade-off relationship between two of the estimated variables after the implementation of IT.

Interestingly, Colombia is the only country that remains the negative coefficient in $\lambda_{1}$ after the adoption of IT. Its R-square value has increased from 0.081886 to 0.216576 . This indicates that the model is more fits better after the adoption of IT. The skewness shown by the d-test is declined. Yet, the error of the equation also becomes smaller after the implement of IT. Besides, we denoted that Spain has a very small and insignificant value in the estimated coefficient of output gap $\lambda_{1}$, that is -1.19E-05.

As a conclusion, there are three trade-off countries during the pre-IT period and four trade-off countries during the post-IT period. Thus, the results are mixed. IT does not necessary lead to trade-off between the output gap and deviation of inflation. 
Table 11. Results of trade-off relationship based on $\pi_{I}{ }^{d}=\lambda_{0}+\lambda_{I}$ gap

\begin{tabular}{|c|c|c|c|c|}
\hline \multirow{2}{*}{ Country } & \multicolumn{2}{|c|}{ Coefficient (Standard Error) } & \multirow{2}{*}{$R^{2}$} & \multirow{2}{*}{ Durbin-Watson sta } \\
\hline & $\lambda_{0}$ & $\lambda_{1}$ & & \\
\hline \multirow{2}{*}{ Korea } & $0.005556^{* * *}$ & -0.01212 & \multirow[t]{2}{*}{0.00712} & \multirow[t]{2}{*}{0.990994} \\
\hline & $(0.000501)$ & $(0.009742)$ & & \\
\hline \multirow{2}{*}{ Spain } & $0.006486^{* * *}$ & 0.010835 & \multirow[t]{2}{*}{0.000132} & \multirow[t]{2}{*}{1.598908} \\
\hline & $(0.000463)$ & $(0.00738)$ & & \\
\hline \multirow{2}{*}{ United kingdom } & $0.005311^{* * *}$ & $0.134835^{* *}$ & \multirow[t]{2}{*}{0.014165} & \multirow[t]{2}{*}{1.497459} \\
\hline & $(0.000307)$ & $(0.067631)$ & & \\
\hline \multirow{2}{*}{ Sweden } & $0.005799 * * *$ & 0.000696 & \multirow[t]{2}{*}{0.000727} & \multirow[t]{2}{*}{1.85479} \\
\hline & $(0.000504)$ & $(0.002086)$ & & \\
\hline \multirow{2}{*}{ Finland } & $0.005152 * * *$ & $0.008432 * *$ & \multirow[t]{2}{*}{0.05494} & \multirow[t]{2}{*}{1.530655} \\
\hline & $(0.000362)$ & $(0.002818)$ & & \\
\hline \multirow{2}{*}{ South Africa } & $0.009397 * * *$ & 0.013277 & \multirow[t]{2}{*}{0.003867} & \multirow[t]{2}{*}{1.674765} \\
\hline & $(0.000394)$ & $(0.013813)$ & & \\
\hline \multirow{2}{*}{ Brazil } & $0.099785^{* * *}$ & $-0.60246^{*}$ & \multirow[t]{2}{*}{0.037441} & \multirow[t]{2}{*}{0.107993} \\
\hline & $(0.01178)$ & $(0.307012)$ & & \\
\hline \multirow{2}{*}{ Colombia } & $0.017074 * * *$ & $-0.041002 * * *$ & \multirow[t]{2}{*}{0.081886} & \multirow[t]{2}{*}{0.862362} \\
\hline & $(0.000588)$ & $(0.009153)$ & & \\
\hline \multirow{2}{*}{ Philippines } & $0.008224^{* * *}$ & $0.040015^{* * *}$ & \multirow[t]{2}{*}{0.049097} & \multirow[t]{2}{*}{0.877699} \\
\hline & $(0.000716)$ & $(0.011138)$ & & \\
\hline \multirow{2}{*}{ Poland } & $0.044215^{* * *}$ & 0.132945 & \multirow[t]{2}{*}{0.015136} & \multirow[t]{2}{*}{0.764412} \\
\hline & $(0.006682)$ & $(0.095536)$ & & \\
\hline \multirow{2}{*}{ Thailand } & $0.003713^{* * *}$ & -0.005026 & 0.004832 & 1.557639 \\
\hline & $(0.000381)$ & $(0.005738)$ & & \\
\hline
\end{tabular}

Note: $* * *$ represents $1 \%$ significance level

** represents $5 \%$ significance level

* represents $10 \%$ significance level

Table 12. Results of trade-off relationship based on $\pi_{2}{ }^{\mathrm{d}}=\lambda_{0}+\lambda_{1}$ gap $_{\mathrm{t}}$

\begin{tabular}{|c|c|c|c|c|}
\hline \multirow{2}{*}{ Country } & \multicolumn{2}{|c|}{ Coefficient (Standard Error) } & \multirow{2}{*}{$R^{2}$} & \multirow{2}{*}{ Durbin-Watson stat } \\
\hline & $\lambda_{0}$ & $\lambda_{1}$ & & \\
\hline \multirow{2}{*}{ Korea } & $0.002302 * * *$ & -0.00297 & 0.002378 & 1.496307 \\
\hline & $(0.000328)$ & $(0.004956)$ & & \\
\hline \multirow{2}{*}{ Spain } & $0.002357 * * *$ & $-1.19 \mathrm{E}-05$ & 0.000000 & 1.463794 \\
\hline & $(0.00032)$ & $(0.002747)$ & & \\
\hline \multirow{2}{*}{ United Kingdom } & $0.002226^{* * *}$ & 0.004764 & 0.003866 & 1.784906 \\
\hline & $(0.000269)$ & $(0.005204)$ & & \\
\hline \multirow{2}{*}{ Sweden } & $0.001316^{* * *}$ & $0.010595 * * *$ & 0.098671 & 1.520361 \\
\hline & $(0.000275)$ & $(0.062222)$ & & \\
\hline \multirow{2}{*}{ Finland } & $0.001254 * * *$ & $0.007581 * * *$ & 0.045786 & 1.775495 \\
\hline & $(0.000205)$ & $(0.002377)$ & & \\
\hline \multirow{2}{*}{ South Africa } & $0.00474 * * *$ & $0.0420 * * *$ & 0.073198 & 1.366952 \\
\hline & $(0.000553)$ & $(0.081304)$ & & \\
\hline \multirow{2}{*}{ Brazil } & $0.005342^{* * *}$ & 0.010104 & 0.00728 & 0.732601 \\
\hline & $(0.000357)$ & $(0.01008)$ & & \\
\hline \multirow{2}{*}{ Colombia } & $0.005414 * * *$ & $-0.038574 * * *$ & 0.216576 & 0.997311 \\
\hline & $(0.000505)$ & $(0.008707)$ & & \\
\hline \multirow{2}{*}{ Philippines } & $0.004135 * * *$ & 0.00462 & 0.006538 & 0.955601 \\
\hline & $(0.000511)$ & $(0.000462)$ & & \\
\hline \multirow{2}{*}{ Poland } & $0.002151 * * *$ & $0.003496 * *$ & 0.032511 & 1.129237 \\
\hline & $(0.000539)$ & $(0.009398)$ & & \\
\hline \multirow{2}{*}{ Thailand } & $0.001403 * * *$ & 0.337172 & 0.001143 & 1.344119 \\
\hline & $(0.000523)$ & $(0.084199)$ & & \\
\hline
\end{tabular}

Note: *** represents $1 \%$ significance level

** represents $5 \%$ significance level

* represents $10 \%$ significance level 


\section{Discussion and Conclusion}

We conduct empirical analyses on evaluating the performance of inflation targeting (IT) in 11 developed and developing countries. The Ordinary Least Squares Approach (OLS) and Panel data Analysis are applied for the purpose of analysis. Under OLS regression, the results reveal significant decline in inflation in all countries. Besides, the output growth has significantly grown higher after the implementation of IT. There is weak evidence that IT has led to higher volatility in exchange rate. In other words, IT manages to boost the economy by leading a higher growth on output, reduction on inflation and does not led to the volatility in exchange rate.

In addition, we make comparison of the IT performance on the group of developing and developed countries by panel data analysis. From the results obtained, we notice that IT works well in both groups of countries. We find that IT has effectively reduced the inflation rate and simulated high output growth. Yet, the results show that the reduction of inflation rate is larger in developing economies but the gain in higher growth is larger in developed economies. From the aspect of exchange rate, there is weak evidence that IT has led to higher volatility in exchange rate in developed countries but distinguish result obtained in developing countries.

Under the OLS regression, the persistency of deviation in inflation, for six out of eleven countries has declined in the post-IT period. For output gap variable, we find that the implementation of IT has no significant impact on the output gap in all countries. There is weak evidence that IT has led to the trade-off relationship between inflation and output gap. To sum up, the results show evidences on better economies condition under IT regime.

\section{References}

Brito, R. D., \& Bystedt, B. (2009). Inflation Targeting In Emerging Economies: Panel Evidence. Development Economics, 91(2), 198-210. http://dx.doi.org/10.1016/j.jdeveco.2009.09.010

Bruderl, J. (2005). Panel data analysis. Retrieved from http://www2.sowi.uni-mannheim.de/lsssm/veranst/Panelanalyse.pdf

Calvo, G., \& Mendoza, E. (2000). Capital-Market Crises And Economic Collapse In Emerging Markets: An Informational-Frictions Approach. Journal American Economic Review, 90(2), 59-64. Retrieved from http://econweb.umd.edu/ mendoza/pp/paper4session.pdf

Capistrán, C., \& Ramos-Francia, M. (2007). Does Inflation Targeting Affect The Dispersion Of Inflation Expectations? Banco de México. Working paper. http://dx.doi.org/10.1111/j.1538-4616.2009.00280.x

Curran, C. (2010). Panel Data Models. The Connexios Project and Licensed Under the Creative Commons Attribution License. Retrieved from http://cnx.org/content/m34551/latest/

Fraga, A., Goldfajn, I., \& Minella, A. (2004). Inflation Targeting In Emerging Market Economies. NBER Eighteenth Annual Conference on Macroeconomics. April 4-5 2003. Cambridge, New York: NEBR. Retrieved from http://www.nber.org/papers/w10019.pdf?new_window=1

Fregert, K., \& Jonung, L. (1998). Monetary Regimes and Endogenous Wage Contracts: Sweden 1908-1995, Lund University, Department of Economics. Working Papers. Retrieved from https://lup.lub.lu.se/luur/download?func=downloadFile\&recordOId=2028937\& fileOId=2028938

Gerlach, S., \& Tillmann, P. (2010). Inflation Targeting And Inflation Persistence In Asia, Unpublished, Goethe-University Frankfurt. Retrieved from http://www.stefangerlach.com/it_in_asia_sept1.pdf

Gosselin, P., Lotz, A., \& Wyplosz, C. (2007). Interest Rate Signals and Central Bank Transparency, NBER International Seminar on Macroeconomics 2007. June 15-16. Istanbul, New York: University of Chicago Press.

Guender, A. V., \& Oh, D. Y. (2006). Price Stability through Price- Level Targeting or Inflation Targeting: A Tale of Two Experiments. Journal of Economics and Business, 58(5-6), 373-391. http://dx.doi.org/10.1016/j.jeconbus.2006.06.002

Kadiǒglu, F., Özdemir, N., \& Yilmaz, G. (2000). Inflation Targeting In Developing Countries. Fourth METU International Conference in Economics. September 13-16, 2000, Ankara. Turkey: The Central Bank of the Republic of Turkey. Retrieved from http://unpan1.un.org/intradoc/groups/public/documents/APCITY/UNPAN018301.pdf

Levin, A. T., Natalucci, F. M., \& Piger, J. M. (2004). The Macroeconomic Effects of Inflation Targeting. Federal Reserve Bank of St. Louis Review, 86(4), 51-80. Retrieved from http://research.stlouisfed.org/publications/review/04/07/LevinNatalucciPiger.pdf

Lin, S., \& Ye, H. (2008). Does Inflation Targeting Make A Difference In Developing Countries? Journal of 
Development Economics, 89(1), 118-123. http://dx.doi.org/10.1016/j.jdeveco.2008.04.006

Mccallum. B. T. (2007). Inflation Targeting For the United States? Cato Journal, 27(2), 261-271. Retrieved from http://www.cato.org/pubs/journal/cj27n2/cj27n2-14.pdf

Mishkin F. S. (2000). Inflation Targeting For Emerging Market Countries. NBER Working Paper 7618. http://dx.doi.org/10.1257/aer.90.2.105

Mishkin, F. S. (2004). Can Inflation Targeting Work In Emerging Market Countries? NBER Working Paper 10646. Retrieved from http://www.nber.org/papers/w10646.pdf?new_window=1

Mishkin, F., \& Schmidt-Hebbel, K. (2007). Does Inflation Targeting Make A Difference? NBER Working Paper 12876. Retrieved from http://www.nber.org/papers/w12876.pdf

Nelson, C. H. (2011). Panel Data, Fixed Effects, Random Effects. Retrieved from https://netfiles.uiuc.edu/chnelson/www/teaching/ace530/lect022311.pdf

Oscar, T. R. (2010). Panel Data Analysis Fixed \& Random Effects (ver. 4.0). Data \& Statistical Services, Data Consultant. Retrieved from http://dss.princeton.edu/training/Panel101.pdf

Pétursson, T. G. (2004). The Effects of Inflation Targeting on Macroeconomic Performance, Central bank of Iceland. Working papers, 23. Retrieved from http://www.sedlabanki.is/uploads/files/WP-23.pdf

Razzak W. A., \& Dennis. (1999). The Output Gap Using The Hodrick-Prescott Filter With A Non-Constant Smoothing Parameter: An Application To New Zealand, Reserve Bank of New Zealand, Discussion paper, 95. Retrieved from http://www.razzakw.net/paper5.pdf

Schmidheiny, K. (2010). Panel Data: Fixed and Random Effects. Short Guides to Microeconometrics. Retrieved from http://www.schmidheiny.name/teaching/panel2up.pdf

Tutar. E. (2002). Inflation Targeting in Developing Countries and Its Applicability to the Turkish Economy. An Unpublished M. A. Economics Thesis Submitted to the Faculty of the Virginia Polytechnic Institute and State University Blacksburg, $\quad$ Virginia. $\quad$ Retrieved from http://scholar.lib.vt.edu/theses/available/etd-08012002-110233/unrestricted/Thesis.pdf 